\title{
Implementation of e-SEKOCI (The Online Class of Sekolah Komplementer Cinta Ibu) in counselling midwives and pregnant women during COVID-19 pandemic
}

\author{
Rizka Ayu Setyani, ${ }^{1}$ Sumardiyono ${ }^{2}$ \\ 'Student of Public Health Doctoral Program, Universitas Sebelas Maret, Surakarta, Indonesia \\ ${ }^{2}$ Public Health Doctoral Program, Universitas Sebelas Maret, Surakarta, Indonesia
}

KEYWORDS

Counselling

COVID-19

e-SEKOCI

Midwife

Pregnant woman

\begin{abstract}
Pregnancy classes are vital for successful communication, information, and health education in maternity services. However, their implementation should be postponed during the COVID-19 pandemic to prevent COVID-19 transmission in pregnant women who are classified as a vulnerable group, especially if they had a history of pregnancy with non-communicable diseases. Therefore, we implemented e-SEKOCI (The Online Class of Sekolah Komplementer Cinta $\mathrm{lbu}$ ) which aimed to provide counselling and mentoring of pregnant women using social media WhatsApp group, Zoom Cloud meeting, Instagram, or YouTube. The implementation of e-SEKOCI began in March 2020 with 150 pregnant women in Indonesia. We also worked with teaching volunteers consisting of midwives and midwifery lecturers. In e-SEKOCI classes, expectant mothers were taught complementary midwifery care, such as mom and baby massage, prenatal and postnatal yoga, and self-hypnosis. Besides, pregnant women could also conduct online consultations with midwives about their pregnancies. Most of the participants said they were satisfied with e-SEKOCl, which included $80 \%$ in the health education program and $94 \%$ in the pregnancy consultation program. As many as $70 \%$ of participants prefer the WhatsApp group as a means of implementing e-SEKOCI. In conclusion, e-SEKOCI was effective as a media of midwife counselling for pregnant women, especially during the COVID-19 pandemic. The use of WhatsApp group media was recommended because it was easier to use and cost-effective.
\end{abstract}

(c) The Journal 2021. This article is distributed under a Creative Commons Attribution-ShareAlike 4.0 International license.

\section{Introduction}

Pregnant women especially those with noncommunicable disease (including hypertension and diabetes) are considered to have an increased risk of developing COVID-19. Therefore, it is important that they take precautions to protect themselves from COVID-19, and report possible symptoms (including fever, cough, or difficulty breathing) to their healthcare provider. ${ }^{1}$

Another problem is the presence of 'fake' news that is not clearly true. Limited access to healthcare during the COVID-19 pandemic, makes pregnant women get information from inaccurate sources. ${ }^{2}$ Some of them are also trying to find out for themselves the truth of the news. Accordingly, this

*Correspondence: rizkaayusetyani@respati.ac.id Midwifery Study Program Bachelor Program, Faculty of Health Sciences, Universitas Respati Yogyakarta, Jl. Raya Tajem Km. 1,5 Maguwoharjo, Depok, Sleman, Yogyakarta, 55282, Indonesia condition of course adds to the anxiety of pregnant women that impacts their mental health. ${ }^{3,4}$

All pregnant women and their newborns have the right to high-quality care before, during, and after childbirth, including mental health care. ${ }^{5}$ However, due to the COVID-19 pandemic, access to maternity services has been limited, including the implementation of maternity classes. The policy from Ministry of Health, calls for immediate health service restrictions to prevent the transmission of COVID-19. This is done especially in Public Health Centers. ${ }^{6,7}$

Technological advances are expected to be the solution to this situation during the COVID-19 pandemic. ${ }^{8}$ Providing counselling, information, and education from midwives to pregnant women can still be done by utilizing modern technology on social media. ${ }^{9}$ Therefore, we offer an innovation project $e$-SEKOCI (Online Class of Sekolah Komplementer Cinta Ibu) as a substitute for pregnant women's classes that are usually carried out directly. We utilize social media WhatsApp, Instagram, and zoom to 
hold web seminars and online consultations. This project is a media for counselling midwives and pregnant women in providing proper education, especially during the COVID-19 pandemic. Pregnant women also do not need to worry because although they cannot come to the Public Health Center, they can still do consultations online. This study aims to evaluate the application of e-SEKOCI during the COVID-19 pandemic.

\section{Method}

The Online Class of Sekolah Komplementer Cinta Ibu (e-SEKOCI) was the development of a pregnant women's class program in collaboration with the Public Health Centers in Indonesia. We were advocating for the Public Health Centers to socialize the program to the target of pregnant women. Additionally, we invited midwives as teaching volunteers in $e$-SEKOCI.

The program started in March 2020 until now after getting ethical clearance (number: 127.3/ FIKES/PL/III/2020). We provide informed consent to participants before the start of this program. There are 150 participants of pregnant women who have been registered with $e$-SEKOCI. We conduct e-SEKOCI promotion directly through Public Health Centers and online through social media to enroll participants. The implementation of $e-\mathrm{SEKOCI}$ included: providing health education every month using social media WhatsApp group, Zoom Cloud meeting, Instagram, or YouTube; and pregnancy consultation via WhatsApp chat. Participants could access these online services for free.

Program evaluation was done every three months. This was a quantitative study and the data were collected with a satisfaction questionnaire. Variables measured were health education program satisfaction, online consulting program satisfaction, and social media usage preferences. Analysis of data was done univariately and presented as percentages in the tables.

\section{Result}

\subsection{The characteristic of the e-SEKOCI participant}

The number of pregnant women who participated were 150 participants spread throughout Indonesia. We collected data of the pregnant women, including age, education, occupation, and pregnancy status. In Table 1, the characteristics of pregnant women (e-SEKOCI participants) are displayed. The average age of them was 27.31 years, with $96 \%$ having a senior high school and university education, $28.67 \%$ worked as a housewife, and $57.33 \%$ currently having their first pregnancy.

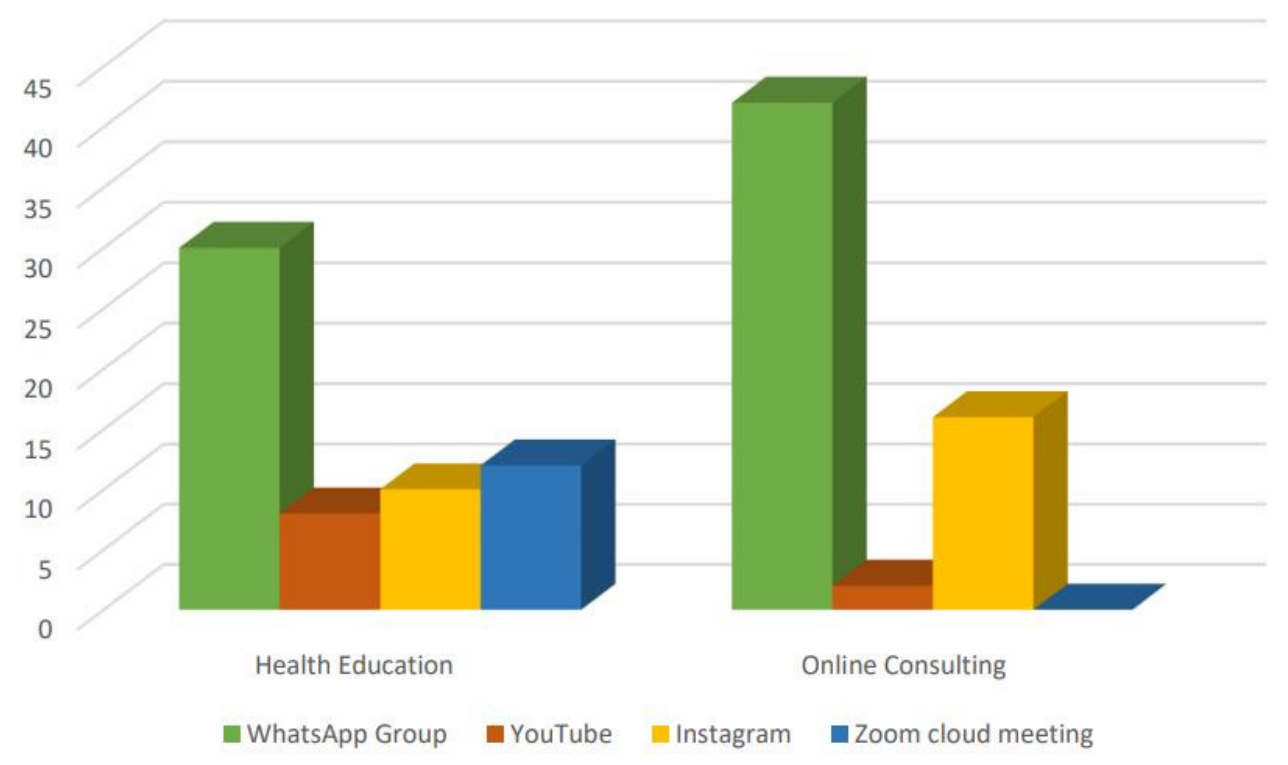

Figure 1. The intensity of e-SEKOCI programs 
Table 1. The characteristics of the e-SEKOCI participants

\begin{tabular}{|c|c|c|}
\hline \multirow[t]{2}{*}{ Characteristic } & \multicolumn{2}{|l|}{$\begin{array}{l}\text { Respondent } \\
(\mathrm{n}=150)\end{array}$} \\
\hline & Mean & n (\%) \\
\hline Age (mean with standard deviation) & $27.31 \pm 4.680$ & \\
\hline \multicolumn{3}{|l|}{ Education level (n\%) } \\
\hline Elementary school & & $2(1.33 \%)$ \\
\hline Junior high school & & $4(2.67 \%)$ \\
\hline Senior high school and university & & $144(96 \%)$ \\
\hline \multicolumn{3}{|l|}{ Occupation (n\%) } \\
\hline Government employee & & $28(18.66 \%)$ \\
\hline Non-government employee & & $40(26.67 \%)$ \\
\hline Entrepreneur & & $39(26 \%)$ \\
\hline Housewife & & $43(28.67 \%)$ \\
\hline \multicolumn{3}{|l|}{ Pregnancy status (n\%) } \\
\hline Primigravida (1st pregnancy) & & $86(57.33 \%)$ \\
\hline Multigravida (2nd - 4th pregnancy) & & $56(37.33 \%)$ \\
\hline Grandemultigravida ( $\geq$ 5th pregnancy) & & $8(5.34 \%)$ \\
\hline
\end{tabular}

Source: Primary data (2020)

Table 2. The satisfaction of the e-SEKOCI program

\begin{tabular}{lll}
\hline Variable & Evaluation $(\mathbf{n}=\mathbf{1 5 0})$ & Not satisfied $(\mathbf{n} \%)$ \\
\cline { 2 - 3 } & Satisfied $(\mathbf{n} \%)$ & $30(20 \%)$ \\
\hline Health education program satisfaction & $120(80 \%)$ & $9(6 \%)$ \\
Online consulting program satisfaction & $141(94 \%)$ & \\
\hline
\end{tabular}

Source: Primary data (2020)

Table 3. Social media usage preferences

\begin{tabular}{ll}
\hline Social media & Preferences $(\mathbf{n}=\mathbf{1 5 0})$ \\
\hline WhatsApp group & $105(70.00 \%)$ \\
YouTube & $22(14.67 \%)$ \\
Instagram & $20(13.33 \%)$ \\
Zoom Cloud meeting & $3(2.00 \%)$ \\
\hline
\end{tabular}

Source: Primary data (2020)

\subsection{Implementation of the e-SEKOCI program}

Overall, the implementation of e-SEKOCI (The Online Class of Sekolah Komplementer Cinta Ibu) followed the schedule and targets. Health education programs in e-SEKOCI (The Online Class of Sekolah Komplementer Cinta Ibu) were offered every month through social media. Figure 1 explains that there are two e-SEKOCI programs, namely health education and online consulting. Social media used to support the program are WhatsApp group, YouTube, Instagram, and Zoom cloud meeting. In health education and online consulting, the most widely used social media is the WhatsApp group. According to the interviews with e-SEKOCI participants, the reason for selecting the WhatsApp group is that participants are easier to use than other social media.

We cooperated with volunteer teachers (midwives and midwifery lecturers) in the implementation of the $e-S E K O C I$ program. Materials presented related to maternal and child health; complementary alternative medicine and therapy in midwifery (massage, yoga, acupressure, hypnotherapy, and herbs). Besides, we implemented the online consultation program with a scheduling system through the social media WhatsApp.

Based on the results of the survey with pregnant women who are participants in $e-\mathrm{SEKOCl}$, this program, can be an alternative in monitoring 
pregnancy despite physical distancing. However, not all health services can be done online, such as physical examinations. Also, not all pregnant women have social media and only some can take advantage of it.

\subsection{The satisfaction of the e-SEKOCI program}

In Table 2, most pregnant women participants were satisfied with the e-SEKOCI program, including the health education program $(80 \%)$, and the online consulting program (94\%).

Social media used in e-SEKOCI was adjusted to the type of material to be delivered, including WhatsApp group, Instagram, YouTube, and Zoom Cloud meeting. Table 3 describes social media usage preferences. Based on the survey results, pregnant women who are $e$-SEKOCl participants as much as $70 \%$ prefer to use the WhatsApp group in accessing the e-SEKOCI program. They said that, WhatsApp group is the easiest and cheapest when used.

\section{Discussion}

The e-SEKOCl program can be an alternative in monitoring pregnancy despite physical distancing. In this program, there are health education and online consulting that make it easier for pregnant women to get correct information related to their pregnancy. The class of pregnant women is very important in providing counselling, information, and education from midwives to patients. This is one of the integrated antenatal care programs, namely counselling. ${ }^{10}$ Pregnant women who take classes during pregnancy can access all information related to the development of their fetus and can reduce discomfort, and anxiety during pregnancy. ${ }^{3,11}$

The use of technology in maternal and child health services must be done, especially in the COVID-19 pandemic. Limited direct access to clinics, Public Health Centers, or hospitals today should not reduce the quality of health services provided. ${ }^{12,13}$ Some previous studies have used tele-health, health applications, or social media as a means to provide these health services. ${ }^{14}$ In this study, we use social media WhatsApp group, Instagram, YouTube, and Zoom Cloud meetings in the implementation of education and health consultation.
The use of social media is influenced by the knowledge and facilities owned by users such as Internet networks, and the ability to purchase Internet quota. A person's level of understanding is also influenced by their age and education. ${ }^{9}$ Among the social media used in $e-\mathrm{SEKOCI}$, WhatsApp group is the most in-demand social media. This is because pregnant women $e$-SEKOCI participants feel that the WhatsApp group is easiest to use and requires only a little Internet quota. In WhatsApp, group features can also fully access videos, text, and voice notes. However, live streaming material delivery cannot be done such as in YouTube, Instagram, and Zoom Cloud meeting.

This study has an impact on the implementation of health services during the COVID-19 pandemic. ${ }^{15}$ The resulting direct output is that pregnant women still get access to proper counselling, information, and health education from health workers and monitoring during pregnancy. While the outcome of this program is the improvement of the quality of health of pregnant women with a good understanding of maternal and child health, including reduced discomfort and stress during pregnancy.

\section{Conclusion}

The e-SEKOCI (The Online Class of Sekolah Komplementer Cinta Ibu) became a class program for pregnant women in demand during the COVID-19 pandemic. The implementation of health education adds to the knowledge of pregnant women, especially about maternal and child health. Besides, pregnant women are also satisfied with the existence of online consultation services. We recommend that this program be continued indefinitely not only during the COVID-19 pandemic. The use of social media can take into account the abilities and desires of participants. WhatsApp can be a good choice because it is easier to use and cost-effective.

\section{Acknowledgements}

The author thanks the Directorate of Research and Community Service, Deputy for Strengthening Research and Development, Ministry of Research and Technology / National Agency for Research and Innovation for providing funding sources for the 
Community Partnership Program (PKM) in 2020. Also, all the teaching and facilitator volunteers who have supported e-SEKOCI program.

\section{Conflict of interests}

In this project, there is no conflict of interest. Funding came from the Ministry of Research and Technology / National Agency for Research and Innovation, who were not involved in the technical planning, implementation, and follow-up of the program.

\section{References}

1. World Health Organization. Coronavirus disease (COVID-19): Pregnancy and childbirth [Internet]. Geneva: World Health Organization; 2020 [updated 2020 September 2; cited 2020 November 23]. Available from: https://www. who.int/news-room/q-a-detail/coronavirusdisease-covid-19-pregnancy-and-childbirth

2. Yanti E, Irman V, Harmawati. Optimalisasi kesehatan ibu hamil selama pandemi COVID-19. Jurnal Abdimas Saintika. 2020;2(2):33-37.

3. Wu Y, Zhang C, Liu H, Duan C, Li Cheng, Fan J, et al. Perinatal depressive and anxiety symptoms of pregnant women during the Coronavirus Disease 2019 outbreak in China. Am J Obstet Gynecol. 2020;223(2):240.

4. Biviá-Roig G, La Rosa VL, Gómez-Tébar M, SerranoRaya L, Amer-Cuenca JJ, Caruso S, Commodari E, Barrasa-Shaw A, Lisón JF. Analysis of the impact of the confinement resulting from COVID-19 on the lifestyle and psychological wellbeing of Spanish pregnant women: an Internet-based cross-sectional survey. Int J Environ Res Public Health. 2020;17(16):5933.

5. Sharma JB, Sharma E, Sharma S, Singh J. Recommendations for prenatal, intrapartum, and postpartum care during COVID-19 pandemic in India. Am J Reprod Immunol. 2020; 84(5):e13336.

6. Kementerian Kesehatan Republik Indonesia. Pedoman Bagi Ibu Hamil, Bersalin, Nifas, dan Bayi Baru Lahir di Era Pandemi COVID-19. Jakarta: Kementerian Kesehatan RI; 2020.

7. Kementerian Kesehatan Republik Indonesia. Petunjuk Teknis Pelayanan Puskesmas pada
Masa Pandemi COVID-19. Jakarta: Kementerian Kesehatan RI; 2020.

8. Bjelke $M$, Martinsson A, Lendahls L, Oscarsson $M$. Using the Internet as a source of information during pregnancy: a descriptive cross-sectional study in Sweden. Midwifery. 2016;40:187-191.

9. Chen M, Liu X, Zhang J, Sun G, Gao Y, Shi Y, et al. Characteristics of online medical care consultation for pregnant women during the COVID-19 outbreak: a cross-sectional study. Research Square. 2020:1-18.

10. Zhang J, Zhang Y, Huo S, Ma Y, Ke Y, Wang P, Zhao A. Emotional eating in pregnant women during the COVID-19 pandemic and its association with dietary intake and gestational weight gain. Nutrients. 2020;12(8):2250.

11. Denton LK, Creeley CE, Stavola B, Hall K, Foltz BD. An analysis of online pregnancy message boards: Mother-to-mother advice on medication use. Women and Birth. 2020;33(1):e48-e58.

12. Grussu P, Quatraro RM, Jorizzo GJ. Supporting perinatal women in the context of the COVID-19 emergency: can web-based antenatal education classes make it possible?. J Reprod Infant Psychol. 2020;38(5):471-473.

13. Wu $D$, Fang $D$, Wang $R$, Deng $D$, Liao $S$. Management of Pregnancy during the COVID-19 Pandemic. Global Challenge. 2020;2000052:1-8.

14. Derya YA, Altiparmak S, Akça E, Gökbulut $N$, Yilmaz AN. Pregnancy and birth planning during COVID-19: The effects of tele-education offered to pregnant women on prenatal distress and pregnancy-related anxiety. Midwifery. 2021;92:102877.

15. De' R, Pandey N, Pal A. Impact of digital surge during COVID-19 pandemic: a viewpoint on research and practice. Int J Inf Manage. 2020;55:102171. 